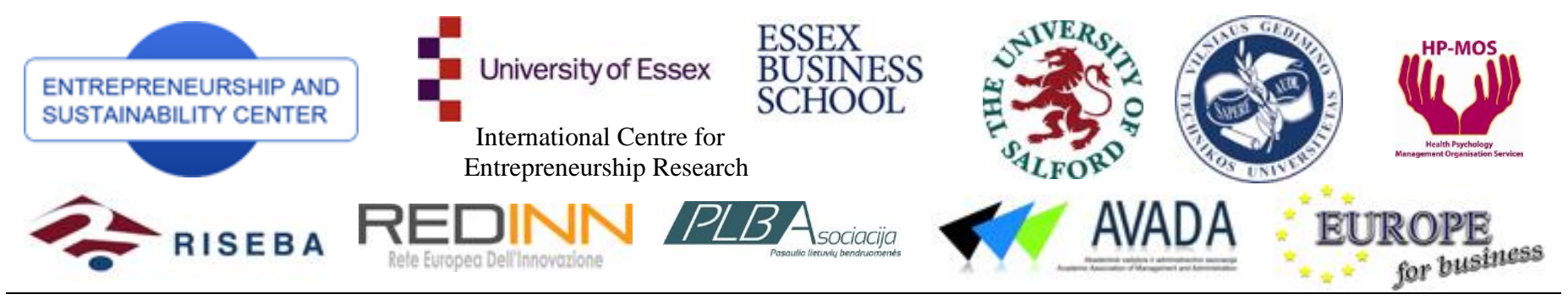

ENTREPRENEURSHIP AND SUSTAINABILITY ISSUES

ISSN 2345-0282 (online) http://jssidoi.org/jesi/aims-and-scope-of-research/

\title{
ENTREPRENEURSHIP IN CREATIVE INDUSTRIES: A CASE OF THEATER FROM ITALY
}

\author{
Francesca Rivetti', Mirella Migliaccioº \\ ${ }^{1,2}$ University of Sannio, Department DEMM, Benevento, Italy \\ E-mails: ${ }^{1}$ francesca.rivetti@unisannio.it; ${ }^{2}$ mirella.migliaccio@unisannio.it
}

Received 26 June 2015; accepted 26 July 2015

\begin{abstract}
Scholars have long overlooked entrepreneurship in the performing arts. The difficulty of making firms operating in these contexts economically self-sufficient and the consequent dependence on public funding have long diverted the attention of scholars from this topic. Only recently, especially thanks to the advancements in theory on entrepreneurship, the phenomenon has begun to be examined in these contexts. This paper, which is mainly based on literature on entrepreneurship and on nascent literature focused on arts entrepreneurship, aims at exploring the entrepreneurial phenomenon with reference to a specific art: the theatre. It is focused on a firm operating in Italy, whose institutional system is characterized to be of particular, although decreasing, support for firms operating in cultural industries. The case study identifies the dimensions of entrepreneurship, declined considering the specificity of the activity and the context in which the firm operates.
\end{abstract}

Keywords: entrepreneurship, performing arts organizations, Italy, case study

Reference to this paper should be made as follows: Rivetti, F.; Migliaccio, M. 2015. Entrepreneurship in creative industries: a case of theater from Italy, Entrepreneurship and Sustainability Issues 3(1): 40-46. .DOI: http://dx.doi.org/10.9770/jesi.2015.3.1(3)

JEL Classifications: L26, M00, Z19

\section{Introduction}

The debate on the entrepreneurial phenomenon (e.g.Vasiliūnaite 2014; Wahl, Prause 2013; Giriūnienè 2013; Baikovs, A.; Zariņš, I. 2013; Laužikas, Mokšeckienè 2013) in the performing arts is not new. Since the 1980s, some scholars, mostly economists, have tried to approach the subject. However, their studies were mostly focused on the aspects that make this sector "problematic" with reference to entrepreneurship (e.g. Baumol, 1967; Baumol \& Brown, 1965), especially accepting a notion of entrepreneurship as a process driven primarily by financial motivations.

Through the phenomenon of the "cost disease", Baumol and Baumol (1985) emphasized the need to financially support these enterprises. In fact, for the Performing Arts Organizations is extremely difficult to survive by relying on the turnover and is therefore essential "a constant flow of contributions" (Baumol \& Brown, 1965, p. 499). This helps to make cultural entrepreneurship a "situated" phenomenon, i.e. a phenomenon anchored to "a national and local political context” (Kolsteeg 2013, p. 14). 
It should be noted that most of the Performing Arts Organizations are traditionally non-profit organizations (Hansmann 1986; see also O'Hagan, Purdy 2003; Rentschler, Geursen 2003), and in this scenario, as DiMaggio (1986) highlighted, private foundations and government institutions play a central role to feed the innovation process to which entrepreneurship tents.

More recently, the role of entrepreneurship a la Schumpeter in this sector has begun to be reevaluated. This could be due, in our opinion, to several phenomena, among which emerge:

- The progressive reduction of the public financial support to the activities of the performing arts Organizations; this has forced entrepreneurs to seek alternative sources of financing and at the same time to find ways to generate more revenue

- The enhancement of some purposes, including the social ones, to which these enterprises normally tend, more and more of interest for scholars.

Some of the debated issues are mostly focused on the individual sphere of the entrepreneur. These include the exploration of the "profiles" of cultural entrepreneurs (e.g. Mulcahy 2003), the entrepreneurial behavior, also in function of the attempt "to reduce subsidy-dependence", balancing artistic freedom and entrepreneurial freedom (Kolsteeg 2013 p. 13), and the pursuit of educational practices that allow artists to gain entrepreneurial skills (e.g. Bonin-Rodriguez 2012; Pollard \& Wilson 2013). For the rest, the entrepreneurial phenomenon in the performing arts is still relatively unexplored; as pointed out by Preece (2011, p. 103), the ways in which the entrepreneurial phenomenon occurs in this context are still not clear.

Stating these premises, this paper aims at exploring the entrepreneurial phenomenon with reference to a specific performing art, and more specifically theatre. Entrepreneurship here is conceived with reference to the exploitation of entrepreneurial opportunities (Alvarez \& Barney, 2007). By considering a case study, the paper identifies the dimensions of entrepreneurship, declined considering the specificity of the activity and the context in which the firm operates.

\section{The dimensions of entrepreneurship}

In order to identify the dimensions of entrepreneurship in the theater, this paper takes into consideration the work of Yalcin \& Kapu (2008), which explore the dimensions of entrepreneurship in transition economies. As will be explained later in the paper, we believe that the dimensions identified in their study can be easily adapted to the performing arts.

Yalcin \& Kapu (2008) examine the dimensions of entrepreneurship considering the entrepreneurial motives, the problems that entrepreneurs face with reference to the particular economic and institutional environment, and the entrepreneurial opportunities pursued. Considering the motives, starting from the relevant literature and in particular by extending the model proposed by Robichaud et al. (2001), they believe that they may be included in the following categories (Yalcin \& Kapu, 2008):

- Financial, linked to the need for economic security and to the desire to earn money

- Recognition, including what contributes to building a social recognition, and in particular "the need for achievement, personal achievement, realize self-actualization, assumes responsibility, desire to innovate, willingness to take risks, exploit personal potential, face challenges, and create employment opportunities" (Yalcin \& Kapu 2008, p. 189)

- Of freedom, concerning the desire to be independent and to control the work of others, and to have an interesting and flexible job

- Family traditions, namely the desire to continue or imitate the work of family members.

Turning to business problems, the authors, on the basis of the relevant literature, refer to: "high taxation, unstable regulations and economic conditions, ineffective banking systems, existence of corruption, prevalence of former business mindset, difficulty in getting capital and loans, and red tape" (Yalcin \& Kapu 2008, p. 193).

Finally, the last dimension relates to the entrepreneurial opportunities pursued.

We believe that the classification proposed by Yalcin \& Kapu (2008) can be adapted to theater organizations operating in the Italian context.

The business problems faced by Italian firms are certainly different from those of a country in transition. However, we argue that this dimension can be considered universally relevant; moreover, the Italian scenario, in 
which this dimension can be specifically declined, is characterized by considerable problems encountered by entrepreneurs in pursuing their business.

\section{Methodology}

This study represents the initial step of a wider project aimed at identifying the dimensions of entrepreneurship in the field of theater. Given its exploratory nature and the paucity of studies on the subject, we decided to opt for a qualitative method that can enable us to understand the dynamics of the phenomenon in the specific sector. More specifically, we consider a single case study (Yin 1994), because it is a particularly effective method to conduct a study of this type.

We selected the specific case for two reasons. First, it is considered particularly relevant for the phenomenon examined; in fact, as will be seen, entrepreneurship is a trait that considerably characterizes the theatrical enterprise considered. Secondly, we considered the possibility of access to secondary data and the availability of the entrepreneurial team.

We used secondary data, related mostly to company documents, and primary data, collected through in-depth interviews. The interviews, seven in all, which were carried out in two years, between 2014 and 2015, were recorded and then transcribed and analyzed. Thus, we identified the dimensions of the entrepreneurial phenomenon, starting from the model proposed by Yalcin \& Kapu (2008).

\section{The case of "Theatre of Naples"}

"Theatre of Naples"" is a non-profit performing arts organization (see Rentschler \& Geursen, 2003) operating in Naples. It represents a particularly important enterprise in theater in the national and international context. Founded in 2000 by a famous actor and director from Naples, has its roots in the mid-80s, when the founder restored and opened to the public an old theater.

In the theater are realized in-house productions, often in collaboration with other organizations, and are hosted outside productions, included in the season's program. In the second half of the $2000 \mathrm{~s}$, it has undergone a generational shift that does not seem to have undermined the original theatrical vocation and has led to an expansion of the offer. The founder's sons, who now make up a heterogenous and cohesive entrepreneurial team, have introduced a series of addictional services. In addition to the ancient theater, today is also used a small theater adjacent to the main one, which hosts "niche" productions. Moreover, the team started to systematically organize cultural events using the spaces of the structure, which hosts also a library and a bistrot, managed in partnership with third sector associations. The old building has become a real cultural hub, a crossroads of a heterogenous audience.

\subsection{The entrepreneurial team}

It has been emphasized that teams strongly characterize cultural industries (Lampel 2006, p. 42). The collective dimension also involves the entrepreneurial sphere. In general, as noted by Gartner, Shaver, Gatewood, and Katz (1994 p. 6), "the locus of entrepreneurial activity often resides not in one person, but in many". This is common in the performing arts, in which the skills required to pursue business opportunities are very different. In fact, pursue business opportunities in this area means (Rentschler \& Geursen 2003, p. 3) to promote diversity in funding (funding from different sources) and creative programming, developing market edges, balancing elite and more popular outputs (Rentschler 2002); this requires very different skills.

The entrepreneurial team is made up of three brothers, sons of the founder, who make up the Board of Directors of the Foundation. The subjects, two males and a female, have between 33 and 42 years. The formation of the team was a result of the generational transition, occurred in the second half of the 2000 s, which has been quite natural, because team members worked for a long time within the family theater.

Two of the team members have a purely artistic background and are graduated in an academy of theater. They have gained experience working as actors and directors in in-house productions, co-productions between the theater and external parties, and in other productions. The only woman of the team, which now holds the

\footnotetext{
${ }^{1}$ In order to preserve the anonymity of the enterprise, we use an invented name.
} 
position of Head of the Foundation, has instead a managerial education. In addition to working intensely in the theater, she has often contributed to the organization of major external events, in cooperation with local authorities.

\subsection{The entrepreneurial motives}

Entrepreneurial motives in this case are certainly not of a financial nature. The realization of a high quality product, in the theater, usually do not ensure significant economic returns; this happens instead for more commercial products, designed in order to capture the broadest public as possible. This has been also emphasized by Gangi (2012, p. 859), who argues that "pecuniary benefits are typically not the primary motivation for starting business ventures" and to carry on a business.

An important role is played by the will to carry on a family tradition, inaugurated by the founder, an actor and director of great renown. The three brothers were involved very soon in the activity of the theatre; they debuted on stage at an early age and they have had an increasingly important role in the management of the theater and the realization of the shows. When the generational transition happened, it was quite natural, and it did not cause any significant problem.

Another aspect of great importance concerns the willingness to contribute to the social community, enriching it from the cultural point of view. It is a very strong motivation, which helped to direct the activities of the theater throughout his life path towards the territory. The team members also emphasize that, through its activities, the Theatre has contributed concretely to retrain an area of Naples that a few decades ago was in a state of deterioration. That area improved significantly, becoming also safer, and today the community associates it immediately to the presence of the theater.

This motivation cannot be simplistically reconducted to the "recognition", proposed by Yalcin \& Kapu (2008), and is similar to the "service to society" mentioned by Gangi (2012). In fact, while it incorporates the intention of being socially recognized and identified as a cultural center, which constitutes an indirect effect, its main objective is to contribute concretely to the cultural growth of the community.

Finally, one last motive can be synthesized in the intention to express themselves freely from the artistic point of view. This motivation, which is not simply the "self-realization" highlighted by Gangi (2012), is especially emphasized by team members who are primarily active in artistic management.

\subsection{The entrepreneurial problems}

The main problems encountered by team members concern different aspects that revolve around the allocation of contributions and support, not always considerable, of local authorities.

Considering the allocation of contributions, vital for the enterprises in the sector, a particularly relevant problem regards the parameters by which the contribution is quantified, based on an evaluation that is not always objective, especially with reference to the "quality" of the artistic output. Another problem, very emphasized, concerns the slowness in the allocation of contributions, the extent of which is communicated after the definition of the artistic program for the year of competence, and more precisely at the time when the program is being implemented. This creates great difficulties in defining the budget and consequently the program for the artistic season; thus, these operations are based mainly on what has been assigned in the past, and the team is stimulated in searching other sources of funding.

Second, the relationship with some local authorities is "complicated", in the sense that the Theatre is not always "supported" enough, and not only in financial terms. This is probably because, despite widespread awareness of the importance of the theater for the cultural development of the area in question and the willingness of the team to reach this objective, local authorities are not enough aware of the need to ensure support and a constant dialogue so that the theater can be facilitated in pursuing its social mission.

\subsection{The entrepreneurial opportunities}

The entrepreneurial team has not simply carried on the activity inaugurated by the founder, focused on theatre. As mentioned earlier, while leaving the theater at the center of the scene, it has revitalized and enriched the offer. First, the team has enriched the strictly theatrical offer, giving rise to a systematic "parallel" program, devoted to 
"niche" productions, hosted in a small theater adjacent to the main one. Second, it began to organize very frequently various cultural events (exhibitions, book presentations, workshops for children, etc.), which take place within the spaces of the ancient building.

Using the spaces of the structure, the team decided to host free a library and a bistro where exhibitions and concerts are held. These initiatives in most cases do not generate a direct economic return for the organization, but reveal the team's ability to detect business opportunities. In this specific case, the enrichment of the offer was designed to change the conception of the organization in the collective imagination. In fact, today it is a cultural point of reference of an increasingly diverse public, not only passionate about theater, but also of literature, music, and dance. In this way, the team was able to pursue more effectively its objectives, especially with reference to the cultural enrichment of the community. Today it is limitative to identify the organization exclusively with the theatrical activity, although this continues to be the "core business". It is a cultural "hub" that enriches the community through a wide range of artistic languages.

\section{Conclusions}

Entrepreneurship in the performing arts is a phenomenon to which scholars are devoting increasing attention, but that has not yet been the subject of systematic investigation.

The purpose of this paper was to contribute to the emerging research on the phenomenon, exploring entrepreneurship with specific reference to a performing art, the theater, in a context, the Italian one, where financial support for enterprises in the sector is very strong, but decreasing in the last years. In considering the dimensions of entrepreneurship, we started from the model Yalcin \& Kapu (2008), applied to the context of the Italian theater, through a single case study.

In the case considered, the locus of entrepreneurship can be identified in a close knit entrepreneurial team, characterized by heterogenous but complementary competences.

The main entrepreneurial motivations that emerge concern the will to carry on a family tradition started by the founder, the intention of contributing to the cultural growth of the local community, and the opportunity of a free artistic expression through internal production.

Considering the main problems encountered in carrying out their entrepreneurial activity, team members highlight the critical issues linked to the allocation of contributions, which is based on very complex parameters, whose evaluation is not always objective; the other relevant problem emphasized concern the slowness in the assignment of the contributions, which does not allow the team to program the seasons with the certainty of have sufficient financial resources, forcing the organization to operate in conditions of great uncertainty. In addition, it was pointed out the problem of the support, not always significant, by local authorities, which recognize the importance of the enterprise for the cultural growth of the community, but do not translate this awareness into a significant support.

Finally, with regard to entrepreneurial opportunities, emphasis is placed on the ability of team members to identify and exploit the opportunity to transform the theater into a real cultural center interwoven into different artistic languages, leaving intact its theatrical vocation, but at the same time enhancing its image and broadening its horizons, thus attracting new audiences.

The scenario that emerges from the case highlights three aspects: the prevalence of "social" and "artistic" motives; problems relating to the assignment of contributions and to institutional support; and the ability to pursue business opportunities. These are, of course, only first evidences which must be confirmed by further research, also with reference to other organizations in the sector. The use of a single case certainly constitutes a limitation of this paper, but has allowed us to explore in detail a phenomenon that had not been addressed previously, albeit through the support of an existing model. Therefore, despite its limitations, this paper could form the basis for future research on the topic. 


\section{References}

Alvarez, S. A., \& Barney, J. B. 2007. Discovery and Creation: Alternative Theories of Entrepreneurial Action. Strategic entrepreneurship Journal 1(1- 2): 11-26.

Baikovs, A.; Zariņš, I. 2013. Philosophical, legal and general issues of legal liability, Entrepreneurship and Sustainability Issues 1(1): 2336. DOI: http://dx.doi.org/10.9770/jesi.2013.1.1(3)

Baumol, H., \& Baumol, W.J. 1985. The Future of the Theatre and the Cost Disease of the Arts. Journal of Cultural Economics, 9, 7-31.

Baumol, W.J. 1967. Performing Arts: The Permanent Crisis. Business Horizons 10(3): 47-50.

Baumol, W.J., \& Brown, W.G. 1965. On the Performing Arts: The Anatomy of Their Economic Problem. American Economic Review, 55(2): 495-502.

Bonin-Rodriguez, P. 2012. What's in a Name? Typifying Artist Entrepreneurship in Community-based Training. Artivate: A Journal of Entrepreneurship in the Arts 1(1): 9-24.

DiMaggio, P.J. 1986. Can Culture Survive in the Marketplace? In P.J. DiMaggio (Ed.), Nonprofit Enterprise in the Arts. Studies in Mission and Constraint. New York: Oxford University Press.

Gangi, J. 2012. Arts Entrepreneurship: An Essential Sub-System of the Artist's Meta-Praxis. 2012 USASBE Conference Proceedings, $859-881$

Gartner, W. B.; Shaver, K.G.; Gatewood, E.; \& Katz, J.A. 1994. Finding the entrepreneur in entrepreneurship. Entrepreneurship Theory and Practice 18: 5-5.

Giriūnienè, G. 2013. Public sector`s subsidies to business - suitability valuation of labor market support measures, Entrepreneurship and Sustainability Issues 1(1): 37-44. DOI: http://dx.doi.org/10.9770/jesi.2013.1.1(4)

Hansmann, H. 1986. Nonprofit Enterprise in the Performing Arts. In P.J. DiMaggio, Nonprofit Enterprise in the Arts. Studies in Mission and Constraint. New York: Oxford University Press.

Kolsteeg, J. 2013. Situated Cultural Entrepreneurship. Artivate 2(3): 3-13.

Lampel, J. 2006. The genius behind the system: The emergence of the central producer system in the Hollywood motion picture industry. In J. Lampel, J. Shamsie, \& T.K. Lant (Eds.), The business of culture: Strategic perspectives on entertainment and media, London: Lawrence Erlbaum Associates Publishers, 41-56.

Laužikas, M.;Mokšeckienė. 2013. The role of creativity in sustainable business, Entrepreneurship and Sustainability Issues 1(1): 10-22. DOI: http://dx.doi.org/10.9770/jesi.2013.1(2)

Mulcahy, K. V. 2003. Entrepreneurship or cultural Darwinism? Privatization and American cultural patronage, The Journal of Arts Management, Law, and Society 33(3): 165-184.

O’Hagan, J.W.P.; \& Purdy, W.M. 1993. O’Hagan, J.W.P., \& Purdy, W.M. 1993. The Theory of Non-Profit Organizations: An Application to a Performing Arts Enterprise, Economic and Social Review 24: 155-167.

Pollard, V.; \& Wilson, E. 2013. The "entrepreneurial mindset" in creative and performing arts higher education in Australia, Artivate: A Journal of Entrepreneurship in the Arts 3(1): 3-22.

Preece, S. B. 2011. Performing Arts Entrepreneurship: Toward a Research Agenda, The Journal of Arts Management, Law, and Society 41(2); 103-120.

Rentschler, R. 2002. The entrepreneurial arts leader: Cultural policy, change and reinvention. University of Queensland Press.

Rentschler, R.; Geursen, G. 2003. Entrepreneurial Leadership in Nonprofit Performing Arts Organisations. AIMAC. In 7th International Conference on Arts \& Cultural Management Proceedings (pp. 1-12). 
Robichaud, Y.; McGraw, E.; Roger, A. 2001. Toward the development of a measuring instrument for entrepreneurial motivation. Journal of Developmental Entrepreneurship 6(2): 189-201.

Vasiliūnaite, R. 2014. Sustainable development: methodological approaches toward issues, Journal of Security and Sustainability Issues 3(3): 69-75.

DOI: http://dx.doi.org/10.9770/jssi.2014.3.3(6)

Wahl, M.; Prause, G. 2013. Toward understanding resources, competencies, and capabilities: business model generation approach, Entrepreneurship and Sustainability Issues 1(2): 67-80. DOI: http://dx.doi.org/10.9770/jesi.2013.1.2(1)

Yalcin, S.; Kapu, H. 2008. Entrepreneurial dimensions in transitional economies: A review of relevant literature and the case of Kyrgyzstan, Journal of Developmental Entrepreneurship 13(02): 185-204.

Yin, R.K. 1994. Case Study Research: Applied Social Research Methods Series. Publications S, ed. Beverly Hills.

Francesca RIVETTI (PhD) is a post-doc research fellow at the University of Sannio (Italy). She has been visiting scholar at Fisher College of Business (The Ohio State University, Columbus OH) during 2011 and at Cass Business School (City University of London) in 2012. Her research interests concern entrepreneurship and innovation as well as knowledge management applied to projects. Last publication are mainly focused on accelerator programs, knowledge spillover, the management of knowledge in projects, Cultural Events and Entrepreneurial Opportunities; and Development of knowledge in the internationalization process.

Mirella MIGLIACCIO is Associate Professor of Management and Innovation at the University of Sannio (Italy). 2011 Visiting Research Scholar at Fisher College of Business, OHIO State University, USA. Last publications regard: Accelerator Programs, Knowledge Spillover, Cultural Events and Entrepreneurial Opportunities; Development of knowledge in the internationalization process; Creativity and Innovation in Tourism, Market Knowledge Exploration.

This is an open access journal and all published articles are licensed under a Creative Commons Attribution 4.0 International License 